\title{
THE IMPACT OF INDIVIDUALISM AND COLLECTIVISM ON THE RELATIONSHIP BETWEEN LEADERSHIP STYLES AND ORGANIZATIONAL CITIZENSHIP BEHAVIOUR
}

\author{
DOI: 10.17261/Pressacademia.2017.755 \\ RJBM-V.4-ISS.4-2017(4)-p.469-484
}

\section{Melda Kececi}

İstanbul Gelisim University, Management Informatıon Systems Department, Istanbul, Turkey. kececi.melda@gmail.com

\section{To cite this document}

Kececi, M., (2017). The impact of collectivism on the relationship between leadership styles and organizational citizenship behavior. Research Journal of Business and Management (RJBM), V.4, Iss.4, p.465-484.

Permemant link to this document: http://doi.org/10.17261/Pressacademia.2017.755

Copyright: Published by PressAcademia and limited licenced re-use rights only.

\begin{abstract}
Purpose - The purpose of this research is to demonstrate the influence of leadership style on organizational citizenship behavior, as employees show individualistic or collectivistic characteristics.

Methodology - 174 white-collar employees (105 males and 69 females) located in Istanbul ( $\mathrm{N}=89)$ and Denizli ( $\mathrm{N}=85)$ formed the sample of this study. A multidimensional questionnaire with six-point interval scale was applied to measure all substantive variables used in this study.

Findings- This research revealed that OCB level in Denizli is significantly higher than the level of OCB level in İstanbul as expected. There is also relationship between some of the leadership styles and OCB. Although both individualism and collectivism have a positive and meaningful correlation with $O C B$, the correlation between collectivism and OCB is stronger in relation to individualism and OCB.

Conclusion-The relationship between leadership style and OCB is moderated by individualism in different ways according to the city. Culture is very important and influential in organizations. It can completely affect the concepts and value perceptions of people, and as a result the leadership styles expected by the employees.
\end{abstract}

Keywords: Organizational citizenship behaviour, individualism, collectivism, leadership styles, cultural differences.

JEL Codes: D23, M14, L20

\section{INTRODUCTION}

In the 2000s, when global competition grew rapidly, companies that were aware of the need to use their resources more efficiently, especially due to the global crises, began looking for different ways to increase their productivity and profitability. In this process, it has been noticed that it is not enough for company managers and employees to fulfill the duties contained in their job descriptions, but to go one step ahead of the task description and to do their own unexpected behavior. Now for companies, it is important that employees embrace the company as if it is their own company and act accordingly.

Since people tend to respond positively to positive behaviors and negatively respond to negative behaviors, there is a significant influence of the behavior of the leaders in the sense that employees feel themselves in their organizations and adopt their organizations as their own (Podsakoff, MacKenzie, Moorman and Fetter, 1990; Podsakoff, MacKenzie, Paine Bachrach, 2000, Podsakoff, MacKenzie and Bommer, 1996). It can be argued that when the employees believe that the leaders care about them and feel that they were treated fairly, the tendency to engage with harmful ways would decrease, and organizational citizenship behaviors would increase.

Although, the relationship between leadership and OCB has been stated before, the strength and direction of this relationship varies according to the personal characteristics of employees (George, 1991, McCrae and Costa, 1987, Moorman and Blakely, 1995) Ramamoorthy, Kulkarni, Gupta Flood, 2007, Ehrhart, 2004, Neubert, Kacmar, Carlson, Chonko and Roberts, 2008, Walumbwa, Hartnell and Oke, 2010). One of the elements that will explain this situation is the dimension of individualism / collectivism. At first, this dimension was at society / culture level, but later it is stated that people may have individualist or collectivist personality traits regardless of the society they are in (Wagner, 1992; Early, 
1989, 1993; Moorman and Blakely, 1995). Therefore, the dimension of individualism / collectivism emerges as a factor that affects the relationship between leadership style and OCB.

In this research, firstly the relationship between leadership styles and OCB will be analyzed in order to understand if the leader can increase or decrease OCB and make his/her subordinates more contributive to the organization. Secondly, the impact of culture on this relationship will be analyzed. Individual may have individualistic or collectivistic characteristics regardless of their nation. However, this study was conducted in different cities to be sure the level of individualism and collectivism differs.

\section{LITERATURE REVIEW}

\subsection{Organizational Citizenship Behavior}

Organizational citizenship behavior (OCB) in simplest form, refers to voluntary and individual extra role behaviors that are aimed at helping, not being directly or explicitly involved in a formal, rewarding, formal reward system, and contributing to the company's productive functioning (Organ 1988). Since these behaviors are voluntary, situations where these behaviors are not present or those who do not show them are not punished. However, the fact that these extra behaviors do not take place in the reward system does not mean they will not be awarded absolutely (Organ, 1997).

Employees showing OCB have a positive attitude, help their colleagues at work, take care of newcomers to adapt to the company, often express their pride in working in their company, protect their company during negative accusations, do not bother to spend long hours at work when necessary, do not get permission unnecessarily, they do not violate the rights of others and avoid problems with their colleagues (Podsakoff et al., 1990).

Organ (1988) has investigated OCB under 5 dimensions: altruism, sportsmanship, civic virtue, conscientiousness and courtesy.

- Altruism is the act of helping someone directly, consciously and willingly helping newcomers for alignment, and supporting employees with more workloads.

- Sportsmanship is a cool way of approaching the possible problems that may arise in the workplace and complaining about them, protecting the positive attitude even in adverse situations and not growing the minor affairs.

- Civic virtue dimension refers not only to expressing ideas but also by actively acting as a part of the organization such as reading electronic mail and letters, participating in meetings and following developments in the organization.

- Conscientiousness includes going beyond the minimum expected roles such as presence and punctuality of organization members, and careful use of resources, etc.

- Courtesy dimension includes the act of avoiding negative situations that may create tension, finding solutions without violating others' rights, and consulting them before they engage in behaviors that may affect their colleagues.

Graham (1989) describes OCB through a quadruple model: (1) interpersonal helpfulness, helping coworkers with work related issues, (2) individual initiative, encouraging others to improve individual and team performance, (3) personal effort, going beyond expected efforts and exceeding the minimum performance, (4) loyalty, improving the corporate image and making an effort to promote the organization to the outside. Williams and Anderson (1991) investigated OCB by dividing them into two at the individual and organizational level. While citizenship behaviors for the benefit of the individual are more like conscientiousness dimension of Organ, behaviors for the benefit of individuals resembles of the dimension of benevolence (Organ and Konovsky, 1989; Smith, Organ and Near, 1983, Wayne and Green, 1993).

When we examine the OCB scales, it is seen that individual initiative and loyalty dimensions from the four dimensions Graham (1989) did not exactly correspond to the five dimensions of Organ (1988). In addition to the five dimensions of the Organ (1988), the individual initiative dimension of Graham (1989) has also been used within the context of this research in order to be able to fully explore the concept of SCL and relate it to other variables to be used in the research.

According to the results of the meta-analysis study of Organ and Ryan (1995) with 55 articles about OCB between 19831994, most important antecedent of OCB is job satisfaction. More recent research by Bettencourt, Gwinner and Meuter (2001) reveal that job satisfaction and perceived organizational support are the most important antecedents of OCB.

Another antecedent of OCB is loyalty. (Organ and Ryan, 1995; Schappe, 1998). Especially, it has been revealed that there is a strong relationship between emotional commitment and OCB (Jenkins, 2005). Other antecedents of OCB include organizational justice (Moorman, 1991, Masterson, Lewis, Goldman, and Taylor, 2000, Penner, Midili and Kegelmeyer, 1997); personality traits such as positive emotional state (George, 1991), agreeableness and conscientiousness (McCrae and Costa, 1987) and engagement (Rich, Lepine and Crawford; 2010). 
OCB increases the productivity of workers and consequently the organization, making existing employees stay and making the organization more attractive for newcomers, helping the organization to adapt to changes, enhancing organizational performance by facilitating interpersonal coordination (Cohen and Vigoda, 2000).

Making employees see the organization as if their own, feel that they belong to that organization, acting according to the interests of the organization inside and outside, be proud of being part of their existing organizations are among the important elements that will bring an organization to long term success. This will increase overall efficiency, as much more work can be done with existing resources, which will reduce the material and spiritual resources spent on organizational harmful behaviors and supervision mechanisms established to reduce these behaviors.

\subsection{The Relationship between OCB and Leadership Styles}

In the GLOBE study, leadership is defined as "an individual influencing and motivating another individual to contribute to productivity and success of their organization (House, Hanges, Javidan, Dorfman, and Gupta, 2004). Daft (2005) defines leadership as an interaction between the leader who aim to achieve real change and output that reflects common purpose, and its followers. Given the characteristics of a successful leader, it is difficult to find a successful leader definition that will be valid in all cultures, organizations and situations. In general, however, it can be argued that employees feel that leaders who are similar to their personal characteristics are successful and feel more attached to these leaders. As different leadership styles effect employee commitment and satisfaction in different ways, it is expected that the OCB will also be affected differently.

There are many studies in the literature that examine the relationship between OCB and leadership style. In these studies, it was argued that the leadership style would affect OCB (Podsakoff et al., 1990, Podsakoff et al., 2000, Podsakoff et al., 1996). The relationship between leadership styles and OCB is based on Social Exchange Theory. According to Social Exchange Theory (Blau, 1964), people react to favorable behaviors in turn voluntarily due to the non-written rules of social relations although they are not obliged to. In other words, there is an unspoken principle of reciprocity, and by doing a favor in return, the other side tries to reach the balance. In view of this theory, employees who receive positively, supportive and promoting behaviors from their leaders, respond with supportive behaviors such as extra role behaviors, benevolence and honesty. In particular, there is a strong relationship between servant (Ehrhart, 2004; Neubert, Kacmar, Carlson, Chonko, \& Roberts, 2008; Walumbwa, Hartnell ve Oke, 2010), transformational, transactional (Podsakoff et. al, 2000) and paternalistic leadership styles and OCB.

In the case of paternalistic leadership, the family metaphor is adapted to the organizations and the father figure who controls and protects is identified with the leader. The leader supports his employees, assists them, and waits for their unquestioning obedience and loyalty in return (Aycan, 2001). However, this leadership style can sometimes be regarded as "dictatorship" in western societies because it is a type of leadership unique to Pacific-Asian cultures such as China, India, Korea and Turkey (Aycan, 2001; Northouse, 1997). Because of this authoritarian leadership in the leadership style, the father-in-leader underestimates the talents of the employees, gives the decisions himself as "I know better than you" perspective, but also reduces the uncertainty for his employees when viewed from the positive direction (Cheng, 1995). It can be thought that the employees who see their leaders as their father tend to see their organization as their own families and show extra role behaviors and try to exceed the expectations in order to increase the performance of the organization.

Hale and Fields (2007) defined the servant leader as the leader type that is focused on the development of followers, rather than thinking about self-interest and glorifying himself. They believe that both their organizations and their employees are influential in the success of their customers and stakeholders, and they behave accordingly (Ehrhart, 2004). Servant leaders create an atmosphere of reciprocity that positively affects employees' attitudes and behaviors, enabling employees to exhibit OCB (Ehrhart, 2004; Liden et al., 2008; Neubert, et al., 2008; Vondey, 2010).

In the meta-analytic study, Podsakoff et al. (2000) have shown that transformational and transactional leadership styles increase OCB. These leadership styles positively affect altruism, courtesy, sportsmanship, civil virtue and conscientiousness dimensions of OCB. Burns (1978) argued that the main difference between the transformational and transactional leaders derives from the process of motivating the subordinates. Transactional leaders motivate employees with pre-determined awards to reach their goals. Transformational leaders, however, motivates their employees to outperform their awards by exceeding their specified awards and values. Motivation to overcome expectations supports employees on the way to extra role behavior and OCB (Bass, 1998). The study of Koh et al. (1995) in elementary schools in Singapore revealed that the relationships between transformational and transactional leadership behaviors and OCB were different.

As defined by Brown, Trevin o, and Harrison (2005) ethical leadership is "the demonstration of normatively appropriate conduct through personal actions and interpersonal relationships, and the promotion of such conduct to followers through two-way communication, reinforcement, and decision making" (p. 120). In other words, ethical leaders are fair, honest, trustworthy, principled and responsible (Brown et al., 2005). When employees have ethical leaders, they may reciprocate 
these honest and fair behaviors by engaging more OCB. Research shows that there is a correlation between ethical leadership and OCB (Piccolo et al., 2010).

Laissez-faire leadership can be described as the passive form of transactional leadership or passive-avoidant leadership (Bass et al., 2003). In this leadership style, the contribution of the leader is very limited in terms of goal setting or providing direction, however if the employees are highly skilled and experienced this could be an effective leadership style (Rowold, \& Heinitz, 2007). Moreover, if the employees are highly individualistic, they may feel autonomy and show more OCB.

Based on all this information, we can develop the following hypothesis:

H1: Leadership style contributes to organizational citizenship behavior.

H1a: Paternalistic leadership has a positive impact on OCB.

H1b: Servant leadership has a positive impact on OCB.

H1c: Transformational leadership has a positive impact on OCB.

H1d: Transactional leadership has a positive impact on OCB.

H1e: Ethical leadership has a positive impact on OCB

H1f: Laissez-faire leadership has a positive impact on OCB

\subsection{Individualism / Collectivism, Leadership Style and OCB}

Parsons and Shills (1951) suggested individualism and collectivism as a way of differentiating between those who think more about their own interests and goals and those who focus on the social system, think more about the interests of the community than themselves. Individualists keep their personal interests ahead of their group's interests, giving priority to reaching their own goals (Earley, 1989; Wagner and Moch, 1986). Competition is one of the main behavioral characteristics of individualism in reaching its goal (Probst et al., 1999). In collectivists, the interests of the group prevent individual interests. At the expense of giving up on personal benefits, the group's well-being and group belonging are important (Wagner, 1992; Wagner and Moch, 1986)

Hofstede (1980) studied national cultures in his work on IBM employees and examined nations under four dimensions: individualism / collectivism, masculine / feminine, uncertainty avoidance and power distance. In this study, Turkey is one of the collectivist cultures. However, this does not mean that everyone living in Turkey adopts collective characteristics. As Hui and Triandis (1986) point out, these results imply that the majority of those living in the country have adopted collective characteristics. The research findings of Kuşdil and Kağıtçıbaşı $(2000$, p. 77) states that "research findings (recent years) show that the value system of the Turkish people cannot be labeled as 'collectivist' or 'individualist' because these values at the group and individual levels are dynamically existing together". Earlier studies (Wagner, 1992; Early, 1989, 1993; Moorman and Blakely, 1995) have proved that people with collectivist or individualistic characteristics can be found within a single country.

When employees work with leaders who are in line with their cultural characteristics their organizational commitment, job satisfaction and performance are positively influenced (Yiing and Ahmad, 2009; Li, 2004). Leaders in collectivist cultures where paternalistic culture is more common are more authoritarian, do not transfer powers and make central decisions, while leaders in individualistic societies with fewer bureaucracy are more inclined to distribute authority and far away from centralized decision making (Chen, 2001; El Kahal, 2002).

For example, the paternalistic leadership style where the father figure in the family is identified with the leader of the organization, emerges in communities high in collectivism, authoritarianism, power distance and uncertainty avoidance. People who grow up in this kind of culture prefer the paternalistic leaders and the atmosphere of trust they have created. However, a person who shows individual characteristics does not want to work with a paternalistic leader who is authoritarian, decides on behalf of his subordinates when making decisions, does not care about his subordinates' opinions, and whose employees are involved not only in business life but also in private life.

Collectivists hold the interests of the group in front of their own benefit, strive for the welfare and success of the group and identify themselves with the group. Making effort for the organization's interests and feeling self-belonging to the group exist in the definition of collectivism, so more OCB exhibits can be expected of those who have collectivist traits. Studies by Moorman and Blakely (1995) and Ramamoorthy et al. (2007) on the relationship between collectivism and OCB have also stated a positive correlation between collectivism and OCB. It is possible that collectivist people will adopt OCBs voluntarily because they feel self-belonging to the organization and put the organization's interests before theirs'. 
Collectivism also has a positive and strong relationship with organizational commitment (Parkes, Bochner and Scheider, 2001, Clugston, Howell and Dorfman, 2000, Ramamoorthy et al., 2007). Collectivist people see their organization as the continuation of their family, feel self-belonging, and care about loyalty. Because they tend to stay in their organizations for a long time, their loyalty is high. It can also be said that since collectivism has a positive influence on organizational commitment, it can also have positive influence on OCB.

However, it would be a mistake to claim that OCB is low in all individualist employees and high in all collectivist workers. Given the relationship between leadership style and $O C B$, this may be the opposite for people working for a leader against his/her personality. Individualist employees who are satisfied working alone individual achievements, and who are seeking more responsibilities may not show OCB because their expectations are not satisfied and they are not happy with their supervisor's behavior. They may even be harmful to the company.

When we look at the contrary, we see that someone from a collectivist family who is accustomed to elderly taking the decisions of the family and the comfort it creates may have problems with a leader who adopts a liberal leadership style and does not show OCB. In the light of these assumptions, we can say that being individualist or collectivist would affect the relation between leadership style and OCB.

$\mathrm{H} 2$ : Individualist or collectivist characteristics of individuals influence the relationship between leadership styles and OCB.

$\mathrm{H} 2 \mathrm{a}$ : The correlation between all types of leadership styles and OCB gets higher when the employee is high in collectivism because there is a correlation between collectivism and OCB.

H2bf: The correlation between laissez-faire leadership and OCB is moderated by individualism. When employees high in individualism enjoy laissez-faire leadership style and feel autonomous, they engage more OCB. However employees high in collectivism would feel insecure and alone which would result in less OCB because they would not see organization as their own.

\section{DATA AND METHODOLOGY}

\subsection{Sample and Data Collection}

The sample group of this study was white collar workers with at least one year of work experience, with university and above education level. At least one year's work experience is to make sure that the subjects have sufficient experience and time to observe the leadership style of the managers. The demographics of the sample group of 174 participants are shown in Table1.

\section{Table 1: Demographics}

Age

$\mathrm{M}$

SD
31,69

6,27

Gender (\%)

Female

35

Male

54,3

Unspecified

10,7

Marital status (\%)

$\begin{array}{ll}\text { Married } & 42,1 \\ \text { Single } & 44,7 \\ \text { Other } & 4 \\ \text { Unspecified } & 11,2\end{array}$

Education level (\%)

$\begin{array}{ll}\text { Undergraduate } & 53,3 \\ \text { Graduate and above } & 36 \\ \text { Unspecified } & 10,7\end{array}$

Position (\%) 
Total experience

\begin{tabular}{ll} 
M & 8,41 \\
SD & 6,79 \\
M & 5,35 \\
SD & 5,05 \\
& \\
Female & 19,3 \\
Male & 66,5 \\
Unspecified & 14,2 \\
& \\
İstanbul & 89 \\
Denizli & 85 \\
\hline
\end{tabular}

\begin{tabular}{llr}
$\begin{array}{llr}\text { Experience in the } \\
\text { current organization }\end{array}$ & M & 5,35 \\
& SD & 5,05 \\
Gender of (\%) & & \\
supervisor & Female & 19,3 \\
& Male & 66,5 \\
& Unspecified & 14,2 \\
City & & \\
& İstanbul & 89 \\
& Denizli & 85 \\
\hline
\end{tabular}

\subsection{Measures of the Study Variables}

In the research, three scales were used; organizational citizenship behavior, leadership style and individualism / collectivism.

OCB was measured by adding the "individual initiative" dimension of the Organizational Citizenship Behavior Scale by Moorman and Blakely (1995), to the five dimension of the Organizational Citizenship Behavior Scale by Podsakoff, MacKenzie, Moorman and Fetter (1990). This scale consists of a total of 29 items, participants were asked to evaluate themselves on a 6-scale scale ranging from "almost always" (6) to "almost never" (1).

The altruism dimension consists of 5 items (eg. helping other employees who are heavily loaded), the courtesy dimension 5 items (eg. avoiding problems with co-workers), the sportsmanship dimension 5 inversely coded items (eg. always have a flaw in what the organization does), the conscientiousness dimension 5 items (eg. I believe we should grant the right to receive money) the civil virtue dimension 4 items (eg. participation in non-compulsory but important meetings) and individual initiative 5 items (eg from my colleagues often to develop ideas for the team).

In the Turkish translation of Podsakoff et al.'s (1990) scale, Göncü's (2006) thesis was used, but some changes were made in the translation of some materials. The translation of the scale of Moorman and Blakely (1995) into Turkish was conducted by the researcher and then evaluated by a four-person academic study group. The reliability value of this scale is $\alpha=.94$ (Fields, 2002).

The "Leadership Style Scale" developed by Çağlar (2011) in his doctoral dissertation was used to measure leadership style. The scale, which deals with transactional, transformational, laissez-faire, ethical, paternalistic and servant leadership styles, is a collection of scales used in the literature in this literature. In this study, Çağlar (2011) has used the Leadership Behavior Scale developed by Podsakoff and colleagues for transactional and transformational leadership styles, the Bass's Multifactor Leadership Questionnaire for liberal leadership style, Aycan and her colleagues' scale for paternalistic leadership, the Ethical Leadership Scale developed by Brown and others for The "Leadership Style Scale" developed by Çağlar (2011) in his doctoral dissertation was used to measure leadership style. After identifying common features, these items were excluded and only measures of deterministic, prominent elements of that leadership style were included. Factor analysis applied by Çăglar gives 3-dimension as developer-liberal-authoritarian. The Cronbach alpha values are $.96, .88$ and .69 respectively. The overall reliability coefficient is .92 .

There are 38 items in the Leadership Style Scale. Participants were asked to evaluate managers on a 6-point scale ranging from "almost always" (6) to "almost never" (1). Transactional leader has 5 items (eg always gives me positive feedback when I perform well), transformational leader 6 items (eg interested in personal and career development of employees, directs them), laissez-faire leader 5 items (eg prefers not to intervene to solve problems ), the paternalistic leader 10 items (eg creates a family environment in the workplace), the ethical leader 6 items (eg, the answer is 'what is the right thing to do' when making the decision), the servant leader 6 items (eg does every to serve its employees).

Triandis (1995) predicts that individualism and collectivism are not only part of society but also of individuals, thus affecting their values, attitudes and behavior. In this direction, the subjective reflection of individualism is called the "autonomous self" and the subjective reflection of collectivism is called the "relational self" (Wasti and Erdil, 2007). In this research, Singelis's "Self Construal Scale" consisting of 30 questions was used to measure individualism and collectivism dimensions at the individual level. Arzu Wasti's, "Measurement of individualism and collectivism values: Self-editing and INDCOL scales in Turkish" was used for the Turkish translation of the scale. On this scale, individualism and collectivism are not regarded 
as contradictory features but as cultural features that can exist in different levels in the same person (Wasti and Erdil, 2007). The reliability value of the Self Construal Scale was reported as $\alpha=.70$. (Singelis, 1994 Act.: Wasti and Erdil, 2007). Participants were asked to rate themselves on a 6-point scale ranging from "completely fit" (6) to "totally contrary".

\begin{tabular}{|l|}
\hline Leadership styles: \\
Paternalistic Leadership \\
Servant Leadership \\
Transformational Leadership \\
Transactional Leadership \\
Ethical Leadership \\
Laissez-faire Leadership \\
\hline
\end{tabular}
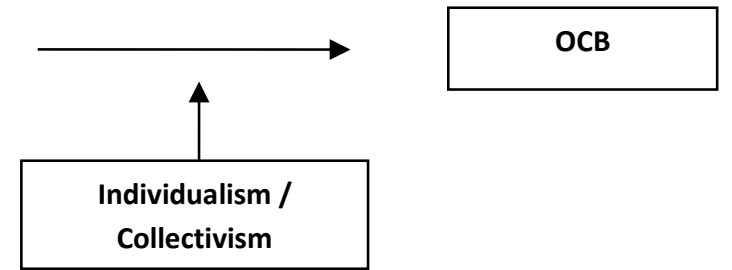

H1: Leadership style contributes to organizational citizenship behavior.

H1a: Paternalistic leadership has a positive impact on OCB.

H1b: Servant leadership has a positive impact on OCB.

H1c: Transformational leadership has a positive impact on OCB.

H1d: Transactional leadership has a positive impact on OCB.

H1e: Ethical leadership has a positive impact on $O C B$

H1f: Laissez-faire leadership has a positive impact on OCB

H2: Individualist or collectivist characteristics of individuals influence the relationship between leadership styles and OCB.

H2a: The correlation between all types of leadership styles and OCB gets higher when the employee is high in collectivism because there is a correlation between collectivism and OCB.

H2bf: The correlation between laissez-faire leadership and OCB is moderated by individualism. When employees high in individualism enjoy laissez-faire leadership style and feel autonomous, they engage more OCB. However employees high in collectivism would feel insecure and alone which would result in less OCB because they would not see organization as their own.

\section{FINDINGS AND DISCUSSIONS}

\subsection{Statistical Analysis}

During the implementation phase, 198 surveys were distributed in total through face-to-face, electronic mail and internet site. Of these, 111 were reached via the internet site, 75 by face-to-face, and 32 by electronic mail. The turnover rate for face-to-face surveys is $88 \%$ and the return rate for those distributed via e-mail is $40 \%$. Since the distribution of the questionnaire via the internet site is based on the snowball method, the return rate is not known. 26 of the total questionnaires (11\%) were eliminated because few questions were answered and 174 questionnaires were analyzed in the last case. However, during the factor analysis, the data of the people who filled in the analysis scale were included only in the analysis of the subject scale.

All data were coded and analyzed by SPSS. All variables were subjected to factor and reliability analyzes after their normal distributions and frequencies were examined, then t-test and ANOVA difference tests, regression analysis were applied. The difference tests are important in terms of measuring the contribution of variables such as gender, education, experience, especially when employees show organizational citizenship behavior and have individualistic / collectivist personality.

By the regression analysis, the strength and direction of the relationship between the variables, and which leader styles influences which organizational citizenship factor were examined.

\subsection{Factor Analysis}

According to the literature review, organizational citizenship behavior scale was expected to have 6 dimensions. However, after removing 3 items because they were loaded under two dimensions at the same time, the scale items were loaded under two dimensions. 
When the questions are carefully examined, it is seen that the behaviors related to self are loaded under the first dimension, while those related to the environment are loaded under the second dimension. For this reason, the first dimension is called Individual $O C B$ and second one Relational $O C B$.

Since the Self- Construal Scale (individualism-collectivism) is a two-factor concept in theory, the scale was forced to twodimensions. Factor analysis shows that the questions were distributed mainly to the dimensions of individualism and collectivism, while some of the individualism elements were loaded under collectivism and vice versa.

The Leadership Style Scale was loaded under 4 dimensions: the first dimension is distant-caring leader because the leader is controlling both himself and its surrounding; the second is the following-caring leader because there are questions about rewarding, the third and the fourth dimensions are paternalistic and servant leaders.

\subsection{Independent t-test Results}

An independent t-test was conducted to determine whether OCB and collectivism varied according to the demographics of the participants. These analyzes shows that it was seen that only the gender of the participants and the supervisors, the place where the participants lived gave a meaningful difference (Table 2). According to the test results, men are more collectivist than women and show more OCB. In addition, employees working for male supervisors are more engaged with OCB than the ones working for female supervisors.

The city where the participants live has a meaningful difference on both OCB and the two sub-dimensions, as well as individualism and collectivism. Participants living in Denizli show more OCB than those living in Istanbul. This situation continues in individual and relational OCB; the collectivism and individualism characteristics of those living in Denizli are higher than those of Istanbul.

Table 2: Independent t-test Results of Demographics

\begin{tabular}{llllllll}
\hline & Gender & $\mathrm{N}$ & Mean & $\mathrm{SD}$ & $\mathrm{t}$ & $\mathrm{df}$ & $\mathrm{P}$ value \\
\hline OCB & Female & 69 & 4.05 & .94 & -3.09 & 151.41 & $.002^{* *}$ \\
& Male & 107 & 4.28 & .65 & & & \\
\hline Collectivism & Female & 68 & 3.25 & 44927 & -3.05 & 141.94 & $.003^{* *}$ \\
& Male & 107 & 3.84 & 44562 & & &
\end{tabular}

\begin{tabular}{|c|c|c|c|c|c|c|c|}
\hline & $\begin{array}{l}\text { Gender of } \\
\text { supervisor }\end{array}$ & $\mathrm{N}$ & Mean & SD & $t$ & $\mathrm{df}$ & $P$ value \\
\hline \multirow[t]{2}{*}{ OCB } & Kadın & 38 & 3.35 & 42736 & -2.27 & 68.14 & $.027^{* *}$ \\
\hline & Erkek & 131 & 3.86 & 12785 & & & \\
\hline
\end{tabular}

\begin{tabular}{llllllll} 
& City & $\mathrm{N}$ & Mean & $\mathrm{SD}$ & $\mathrm{t}$ & $\mathrm{df}$ & $\mathrm{p} \mathrm{value}$ \\
\hline Individual OCB & İstanbul & 88 & 2,15 & 0,50 & $-23,070$ & 195 &, $000^{* * *}$ \\
& Denizli & 109 & 4,76 & 0,96 & & & \\
\hline Relational OCB & İstanbul & 88 & 2,59 & 0,59 & $-14,938$ & 195 &, $000^{* * *}$ \\
& Denizli & 109 & 4,24 & 0,89 & & & \\
\hline Collectivism & İstanbul & 76 & 2,24 & 0,41 & $-21,689$ & 183 &, $000^{* * *}$ \\
& Denizli & 109 & 4,43 & 0,81 & & &, $000^{* * *}$ \\
\hline Individualism & İstanbul & 77 & 3,13 & 0,67 & $-5,400$ & 174,09 & \\
& Denizli & 109 & 3,69 & 0,75 & & &, $000^{* * *}$ \\
& İstanbul & 88 & 2,30 & 0,47 & $-22,022$ & 195 & \\
\hline OCB & Denizli & 109 & 4,58 & 0,87 & & & \\
& & & & & & & \\
\hline
\end{tabular}




\subsection{One-Way ANOVA Results}

A one-way ANOVA test was administered to see whether OCB and collectivism varied according to the position of employees. According to the results of the analysis, both variables differ according to the fact that the employees are supervisors, specialists or assistants (Table 5.6). According to the Scheffe test results, there is no OCB difference but employees in supervisory positions show more collectivistic characteristics than positions (Table 3).

Table 3: ANOVA Test Results According to Positions

\begin{tabular}{|c|c|c|c|c|c|c|c|}
\hline & Position & $\mathbf{N}$ & Mean & SS & $\mathbf{F}$ & df & $p$ value \\
\hline \multirow[t]{3}{*}{ OCB } & Supervisor & 47 & 3,91 & 1,38 & \multirow[t]{3}{*}{3,97} & \multirow[t]{3}{*}{171} & \multirow[t]{3}{*}{,021* } \\
\hline & Specialist & 69 & 3,95 & 1,30 & & & \\
\hline & Assistant & 58 & 3,34 & 1,24 & & & \\
\hline \multirow[t]{3}{*}{ Collectivism } & Supervisor & 46 & 3,88 & 1,24 & \multirow[t]{3}{*}{4,72} & \multirow[t]{3}{*}{170} & \multirow[t]{3}{*}{, $01^{* *}$} \\
\hline & Specialist & 69 & 3,79 & 1,19 & & & \\
\hline & Assistant & 58 & 3,22 & 1,26 & & & \\
\hline
\end{tabular}

$* p<0.05 ; * * p<0.01 ; * * p<0.001$

Table 5.7: Scheffe Test Results

\begin{tabular}{llll}
\hline Position & N & M & M \\
\hline Assistant & 58 & 3,2232 & \\
Specialist & 69 & 3,7948 & 3,7948 \\
Supervisor & 46 & & 3,8764 \\
p value & &, 051 &, 940 \\
\hline
\end{tabular}

\subsection{Correlation Results}

In the correlation analysis, a positive and meaningful relationship was found between OCB and all leader styles except servant leader. Although both individualism and collectivism have a positive and meaningful correlation with OCB, the correlation between collectivism and OCB is stronger in relation to individualism and OCB. Hypothesis 1 , which suggests that leadership styles have an impact on $O C B$, is thus supported.

The fact that the correlation between paternalistic and servant leader, and distant-caring leader and collectivism is higher than .70 reveals that there is a multiple correlation between these variables. Therefore, the servant leader and collectivism variables will not be included in the regression analyzes. The servant leader was chosen as the variables to exclude from the analysis because there was no correlation with $O C B$, and the correlation between collectivism and OCB is lower than the correlation between collectivism and following-caring leadership.

Table 4: Mean, Standard Deviation and Correlations

\begin{tabular}{lllllllllll}
\hline Variables & M & SD & $\mathbf{1}$ & $\mathbf{2}$ & $\mathbf{3}$ & $\mathbf{4}$ & $\mathbf{5}$ & $\mathbf{6}$ & $\mathbf{7}$ & $\mathbf{8}$ \\
\hline 1. Distant-caring I. & 3,70 & 1,26 & & & & & & & & \\
2. Following-caring I. & 3,59 & 1,20 &, $688^{* *}$ & & & & & & & \\
3. Paternalistic I. & 3,71 & 1,20 &, $524^{* *}$ &, $683^{* *}$ & & & & & & \\
4. Servant I. & 3,68 & 1,08 &, $427^{* *}$ &, $639^{* *}$ &, $715^{* *}$ & & & & & \\
5. Individual OCB & 3,60 & 1,52 &, $785^{* *}$ &, $325^{* *}$ &, $160^{* *}$ &, 036 & & & & \\
6. Relational OCB & 3,50 & 1,12 &, $672^{* *}$ &, $308^{* *}$ &, $211^{* *}$ &, 101 &, $861^{* *}$ & & & \\
7. Collectivism & 3,53 & 1,27 &, $736^{* *}$ &, $293^{* *}$ &, 149 &, 017 &, $955^{* *}$ &, $845^{* *}$ & & \\
8. Individualism & 3,45 & 0,76 &, $345^{* *}$ &, $158^{*}$ &, $243^{* *}$ &, $154^{*}$ &, $459^{* *}$ &, $407^{* *}$ &, $469 * *$ & \\
9. OCB & 3,56 & 1,35 &, $778^{* *}$ &, $331^{* *}$ &, $180^{*}$ &, 056 &, $989^{* *}$ &, $926^{* *}$ &, $953^{* *}$ &, $458^{* *}$ \\
\hline
\end{tabular}

${ }^{*} p<0.05 ;{ }^{* *} p<0.01 ;{ }^{* * *} p<0.001$ 


\subsection{Regression Results}

Correlation analysis shows that there is a relationship between variables, but it does not give information about its direction. For these reasons, a step-wise regression analysis was performed to find independent variables describing the dependent variable, OCB. Collectivism and servant leadership were removed from the analyses not to have multiple correlations.

As a result of the step-wise regression analysis, it was found that the most influential variable of the OCB was the city where the participants live (Table 5). There is a positive correlation between the OCB and the city where the participants live, distant-caring leadership and individualism, and a negative correlation between following-caring and paternalistic leadership.

\section{Table 5: Step-Wise Regression}

\begin{tabular}{|c|c|c|c|c|c|c|c|c|}
\hline $\begin{array}{l}\text { Independent } \\
\text { variables }\end{array}$ & $\mathbf{R}$ & $\mathrm{R}^{2}$ & $\Delta \mathrm{R}^{2}$ & $\mathbf{F}$ & $\Delta \mathrm{F}$ & $\beta$ & $\mathbf{t}$ & $p$ value \\
\hline (Constant) & .906 & .821 & .09 & 153,53 & .005 & & 3,422 & ,001 \\
\hline City & & & & & & ,418 & 8,586 &, $000 * * *$ \\
\hline Distant-caring I. & & & & & & ,609 & 9,521 &, $000 * * *$ \\
\hline Following-caring I. & & & & & &,- 127 & $-2,331$ &, $021 *$ \\
\hline Individualism & & & & & & 151 & 4,170 &, $000 * * *$ \\
\hline Paternalistic I. & & & & & &,- 136 & $-2,876$ &, $005 * *$ \\
\hline
\end{tabular}

Hierarchical regression was conducted to find out whether individualism played a moderating role in relationship between leadership style and OCB, and different results were obtained for Istanbul and Denizli (Table 6). According to the participants in Istanbul, individualism affects the relationship between all forms of leadership and OCB as a moderating variable. While this correlation is only positive for the following-caring leader, negative for the distant-caring and paternalistic leaders. In other words, as individualism increases, the contribution of the following-caring leadership to OCB increases, whereas in the paternalistic and distant-caring leadership to OCB decreases with the contribution of individualism.

When we look at Denizli, it is seen that there is a negative and meaningful correlation between following-caring leader and individualism. As the individualism of the employees having following-caring leaders in Denizli increases, that of OCB decreases. Thus, Hypothesis 2, which suggests that individualism and collectivism play a moderating role between leadership styles and $O C B$, is partially supported.

Table 6: Regression Table for İstanbul and Denizli

\begin{tabular}{|c|c|c|c|c|c|c|c|c|c|}
\hline \multirow[t]{2}{*}{ City } & \multicolumn{9}{|l|}{ Independent } \\
\hline & Variables & $\mathbf{R}$ & $\mathbf{R}^{2}$ & $\Delta \mathrm{R}^{2}$ & $\mathbf{F}$ & $\Delta \mathbf{F}$ & $\beta$ & $\mathbf{t}$ & p value \\
\hline \multirow[t]{8}{*}{ İstanbul } & (constant) & 0,608 & 0,37 & 0,108 & 4,61 & 0,032 & & 3,348 & ,001 \\
\hline & Distant-caring & & & & & &,- 086 &,- 263 & 793 \\
\hline & Following-caring & & & & & &,- 072 &,- 365 & ,716 \\
\hline & Paternalistic & & & & & &,- 375 & $-2,208$ & ,031 \\
\hline & Individualism & & & & & & ,476 & 3,896 &, $000 * * *$ \\
\hline & $\begin{array}{l}\text { Distant-caring_ } \\
\text { individu._centered }\end{array}$ & & & & & &,- 602 & $-2,024$ & ,048* \\
\hline & $\begin{array}{l}\text { Following-caring__ } \\
\text { individu._centered }\end{array}$ & & & & & & ,405 & 2,088 &, $041 *$ \\
\hline & $\begin{array}{l}\text { Paternalistic_ } \\
\text { İndividu._centered }\end{array}$ & & & & & &,- 414 & $-2,226$ & ,030* \\
\hline \multirow[t]{4}{*}{ Denizli } & (constant) & 0,740 & 0,547 & 0,03 & & 0,089 & & 3,014 & ,003 \\
\hline & Distant-caring & & & & & & ,964 & 8,688 & ,000 \\
\hline & Following-caring & & & & & &,- 128 & $-1,114$ & , 268 \\
\hline & Paternalistic & & & & & &,- 146 & $-1,387$ & 168 \\
\hline
\end{tabular}




\begin{tabular}{|c|c|c|c|}
\hline Individualism & 182 & 2,328 & ,022* \\
\hline $\begin{array}{l}\text { Distant-caring_ } \\
\text { individu._centered }\end{array}$ &,- 264 & $-2,502$ & ,014* \\
\hline $\begin{array}{l}\text { Following-caring_ } \\
\text { individu._centered }\end{array}$ & ,013 & 144 & ,886 \\
\hline $\begin{array}{l}\text { Paternalistic_ } \\
\text { Individu._centered }\end{array}$ &,- 047 &,- 498 & ,619 \\
\hline
\end{tabular}

${ }^{*} p<0.05 ;{ }^{* *} p<0.01 ;{ }^{* * *} p<0.001$

When the participants did not distinguish according to the city they live in, although leadership styles and individualism have influence on $O C B$, no significant interaction between these variables could be found (Table 7). Leadership style and OCB correlation is not affected by participants' individualism levels.

Table 7: Hierarchical Regression

\begin{tabular}{|c|c|c|c|c|c|c|c|c|}
\hline $\begin{array}{l}\text { Independent } \\
\text { variable } \\
\end{array}$ & $\mathbf{R}$ & $\mathbf{R}^{2}$ & $\Delta \mathrm{R}^{2}$ & $\mathbf{F}$ & $\Delta \mathrm{F}$ & $\beta$ & $\mathbf{t}$ & $p$ value \\
\hline (constant) & 0,864 & 0,746 & 0,005 & 68,937 & 0,381 & & 1,638 & ,103 \\
\hline Distant-caring & & & & & & 0,95 & 16,262 &, $000 * * *$ \\
\hline Following-caring & & & & & & $-0,193$ & $-2,96$ &, $004 * * *$ \\
\hline Paternalistic & & & & & & $-0,246$ & $-4,335$ &, $000 * * *$ \\
\hline Individualism & & & & & & 0,232 & 5,135 &, $000 * * *$ \\
\hline $\begin{array}{l}\text { Distant-caring_ } \\
\text { individu._centered }\end{array}$ & & & & & & $-0,021$ & $-0,477$ & 0,634 \\
\hline $\begin{array}{l}\text { Following-caring_ } \\
\text { individu._centered }\end{array}$ & & & & & & 0,042 & 0,743 & 0,458 \\
\hline $\begin{array}{l}\text { Paternalistic_ } \\
\text { Individu._centered }\end{array}$ & & & & & & $-0,089$ & $-1,548$ & 0,124 \\
\hline $\begin{array}{l}\text { Distant-caring_ } \\
\text { individu._centered }\end{array}$ & & & & & & & & \\
\hline
\end{tabular}

\subsection{2x2 ANOVA and MANOVA Results}

In order to determine how the interaction between demographics was influencing OCB, 2X2 ANOVA analysis was conducted. The results of the analyzes revealed that the interaction between total work experience and seniority at the current job, and the interaction between the gender of the participant and the city where it lives are significant (Table 8 , Graph 1 and Graph 2).

Table 8: 2X2 ANOVA Results

\begin{tabular}{lllll}
\hline Dependent variables & df & Mean2 & F & p value \\
\hline Total experience & 1 & 1,932 & 1,127 &, 290 \\
$\begin{array}{l}\text { Seniority at the current job } \\
\begin{array}{l}\text { Total experience* Seniority at the } \\
\text { current job }\end{array}\end{array}$ & 1 & 4,631 & 2,702 &, 102 \\
\hline Dependent variables & df & 8,351 & 4,873 &, $029^{*}$ \\
\hline City & 1 & Mean2 & $\mathbf{F}$ & p value \\
Gender & 1 & 187,97 & 342,76 &, $000^{* * *}$ \\
City*Gender & 1 & 0,09 & 0,17 & 0,685 \\
\hline
\end{tabular}

Dependent variable: $\mathrm{OCB}$

* $p<0.05$; ** $p<0.01$; ** $p<0.001$ 
Graph 1: OCB level according to seniority and total experience

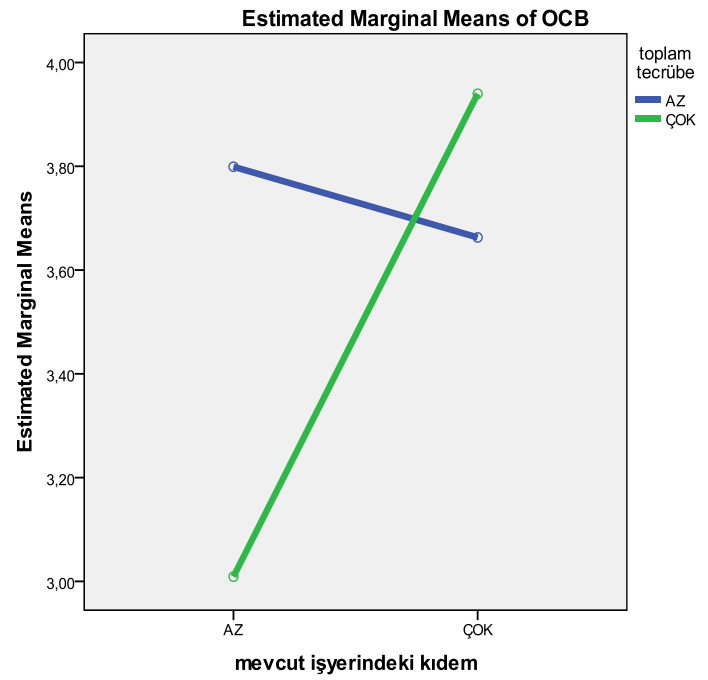

Graph 2: OCB level according to gender and city

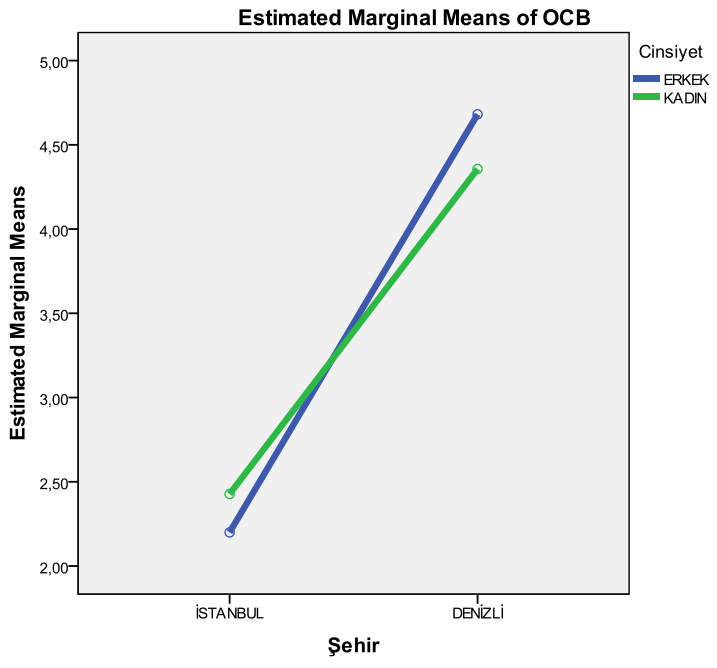

As can be seen in Graph 1, while the employees with high total experience but low seniority have lower levels of OCB, their OCB significantly increase as their seniority increase. In Graph 2, it has been shown that the OCB levels of the participants change according to the city they live in, not to their genders as Denizli residents have higher levels of OCB.

In order to understand the relationship between the interaction of demographics and the two subscales of the OCB (Individual OCB and Relational OCB) 2X2 MANOVA analysis was conducted. As a result of this analysis, it was found that the only characteristic that influences the relationship with both dependent variables is the gender of the employees and that the interaction of the employee and the supervisor gender has no meaningful effect (Table 9, Graphs 3 and 4). Graph 3 and 4 show that the gender of the employee is more influential than the gender of the supervisor in both OCB dimensions.

Table 9: 2X2 MANOVA Results

\begin{tabular}{llllll}
\hline $\begin{array}{l}\text { Independent } \\
\text { variables }\end{array}$ & Pillai's Trace & $\begin{array}{l}\text { Wilks' } \\
\text { Lambda }\end{array}$ & df & Mean2 & F \\
\hline Supervisor gender & 0,246 & 0,246 & 1 & 187,97 & 1,42 \\
$\begin{array}{l}\text { Gender } \\
\begin{array}{l}\text { Supervisor gender* } \\
\text { Gender }\end{array}\end{array}$ & $0,031^{*}$ & $0,031^{*}$ & 1 & 0,09 & 3,54 \\
\hline
\end{tabular}


Graph 3: Individual OCB level according to employee and supervisor gender

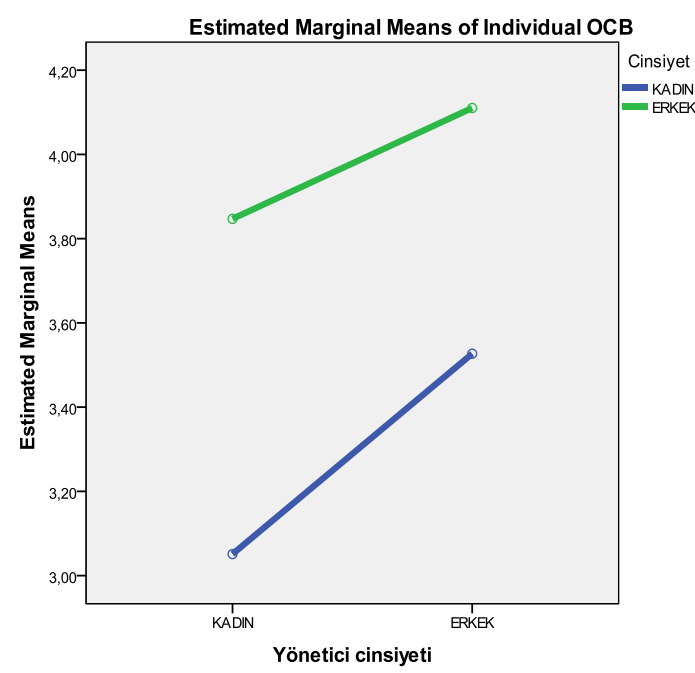

Graph 4: Relational OCB level according to employee and supervisor gender

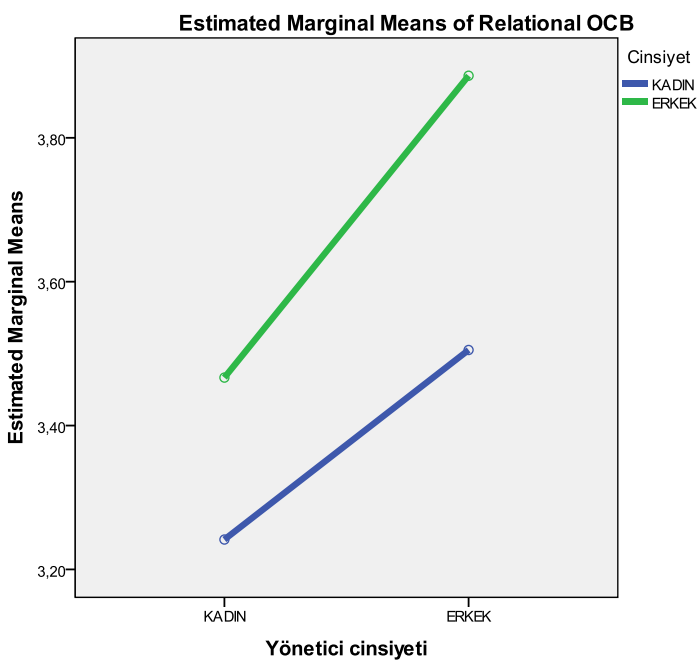

\section{CONCLUSION}

In this research, the relationship between leadership styles and individualism / collectivism and OCB was examined. As a result of the research, it is revealed that there is a relation between leadership style and OCB, and in some cases, individualism plays a moderating role in this relationship. The factor analysis revealed 4 types of leadership in this study: following caring, distant-caring, paternalistic and servant. Although following-caring and distant-caring leadership styles do not exist in the previous literature, they are found to be more influential on OCB. Both of these leadership styles are highly caring about the employees while following caring is more about rewarding, distant-caring is more about controlling. When there is no categorization of the city, distant-caring is the most effective leadership style on $O C B$ and the servant leadership style has no impact at all.

However, the most interesting result is differences about the individualism / collectivism and OCB levels according to the cities they live in. In this research, the individualism/collectivism of individuals were analyzed rather than the total collectivism level of the city. OCB is most significantly influenced by the city the participants live in. In specific, there is a strongly significant difference between the OCB levels of participants living in İstanbul and Denizli. In Denizli, the OCB level is significantly higher.. When the differences between Istanbul and Denizli are examined, it can be seen that Denizli is more collectivist and has higher levels of OCB. Istanbul has different characteristics than Anatolian cities because it is the biggest and most cosmopolitan city of Turkey and more influenced by the western culture. It was expected that those living in İstanbul would be more individualistic, less caring about their relationship but more focused on their own interests.

In a mostly collectivist society like Turkey, it was expected that, men who are given more freedom and more courageously expressing themselves will have more individualistic characteristics while women are more helpful, more caring about relationships and more collectivist. However, there research results show the opposite. According to the independent $t$ test results, men show more OCB than women and are more collectivist. The reason could be the fact that, in recent years, women have also had the opportunity to rise to high positions in the business world and in order to be able to compete with men in this world they have adopted some of the more masculine features attributed to men. It was seen that the gender of the supervisors is only influential on OCB. Regardless of the gender of the employee, it has been demonstrated that employees working for male supervisors have higher levels of OCB.

Age could explain the fact that supervisors are more collectivist than other lower-level employees and have higher levels of OCB. The new generation in Turkey is more individualistic than the previous one, and grows up with suggestions from both family and friends that $s /$ he should give the most importance to himself/herself. Employees in the upper position may be thought to be more collectivistic by their age, and therefore show a higher level of OCB. 
In line with the independent t-test results, regression analysis results also show the differences on OCB between Istanbul and Denizli. As shown in Table 10, the individualist employees working with distant-caring leaders have lower levels of OCB in both cities. The reason for this may be that the individual does not like being controlled in the business and wants to be independent. These employees may not want to show extra role behaviors when they are told what to do.

In İstanbul, the relationship between following-caring leadership and OCB is positively moderated by individualism. In other words, as individualism increase the OCB level of employees working for following-caring leaders increase as well. This can be explained by the rewarding nature of following-caring leadership. Employees with high level of individualism would be more pragmatic about their gains and they would make more emphasis on individual interests. Their motive for OCB would not be the satisfying feelings of being beneficial to the organization but actual and individual rewards. In addition to this, in İstanbul, the relationship between distant-caring leadership and OCB is negatively moderated by individualism. Employees with high levels of individualism would be disturbed by the controlling nature of distant-caring leaders and would be more reluctant to show OCB. In Denizli, there is different scenario about following-caring leadership. As opposed to İstanbul, the relationship between following-caring leadership and OCB is negatively moderated by Individualism which means as the level of individualism increase, employees working for following-caring leaders show lower levels of OCB.

In terms of total experience and seniority, in both cities, while total experience has no significant contribution to $O C B$, seniority has positive contribution. As seniority increase, the level of OCB increase as well. This situation can be explained by the affective commitment and identification with the organization. As the length of time increase, the employee has more friends and more positive feelings to the organization. $\mathrm{S} /$ he feels belonging and identification and as a result shows more OCB.

This research reveals the fact that culture is very important and influential in organizations. It can completely affect the concepts and value perceptions of people. For this reason, when there is distinguishment between politeness and conscience in one culture, these two concepts may have the same meaning in another culture. This may be the reason why the scale of Leadership Style and OCB used in the research were loaded under different dimensions than the original ones in the literature. A similar study conducted with the scale developed in Turkey may lead to different results in the research.

One of the limitations of this research is the fact that the data has been distributed in different ways, including internet site, electronic mail and face-to-face distribution. The Participant quantity per question has remained quite low, especially in the Leadership Style Scale. Secondly, the scales used are developed in foreign cultures. Since the concepts may have different inner meaning for each culture, the origin of the scale may effect research results. The research can be repeated with scales developed in Turkey in order to see whether the results would change.

\section{REFERENCES}

Aycan, Z. (2001). Human resource management in Turkey - Current issues and future challenges. International Journal of Manpower, 22 (3), $252-260$

Bambale, A. J., Shamsudin, F. M. and Subramaniam, C. A (2011). Stimulating organizational citizenship behavior (OCB) research for theory development: Exploration of leadership paradigms. International Journal of Academic Research in business and Social Sciences, 1, 48-69

Bass, B.M. (1998). Transformational Leadership: Industrial, Miliary and Educational Impact, Lawrence Erlbaum Associates, Mahwah, NJ

Bass, B. M., Avolio, B. J., Jung, D. I., \& Berson, Y. (2003). Predicting unit performance by assessing transformational and transactional leadership. Journal of Applied Psychology, 88(2), 207-218. Bettencourt, L.A., Gwinner, K.P., and Meuter, M.L. (2001). A comparison of attitude, personality, and knowledge predictors of service-oriented organizational citizenship behaviors. Journal of Applied Psychology, 86 (1), 29-41.

Blau, P. M. (1964). Exchange and Power in Social Life. New York, NY: Wiley.

Brown, M. E., Trevin o, L. K., \& Harrison, D. A. (2005). Ethical leadership: A social learning perspective for construct development and testing. Organizational Behavior and Human Decision Processes, 97, 117-134

Burns, J. M. (1978). Leadership. New York: Harper \& Row.

Çağlar, E.S. (2011). The impact of empowerment on work engagement, mediated through psychological empowerment: Moderating roles of leadership styles and work goals. Marmara Üniversitesi, Sosyal Bilimler Enstitüsü, Organizational Behavior Bilim Dalı Doktora Tezi

Chen, M. (2001). Asian management systems. London: Thomson Publishing

Cheng, B.S. (1995). The relationship between parent's authority and leadership behaviors: A case study of president of a Taiwanese enterprise. Taipei: Collection of Articles, Institute of Ethnology, Sinica, 79, 119-173.

Clugston, M., Howell, J.P. \& Dorfman, P.W. (2000). Does cultural socialization predict multiple bases and foci of commitment? Journal of Management, 26, 5-30 
Cohen, A. and E. Vigoda. (2000), Do Good Citizen Make Good Organizational Citizens? An Empirical Examination of the Relationship Between General Citizenship and Organizational Citizenship Behavior in Israel. Administration and Society, 32 (5), $596-625$.

Daft, R.L. (2005). The Leadership Experience (3rd ed.), Vancouver: Thomson-Southwestwern

Earley, P. C. (1989). Social loafing and collectivism: A comparison of the United States and the People's Republic of China. Administrative Sciences Quarterly, 34, 565-581.

Earley, P. C. (1993). East meets West meets Mideast: Furtherexplorations of Collectivistic and individualistic work groups. Academy of Management Journal, 36, 319-348.

Ehrhart, M.G. (2004). Leadership and procedural justice climate as antecedents of unit-level organizational citizenship behavior. Personnel Psychology, 57, 61-94.

El Kahal, S. (2002). Business in Asia Pasific. Oxford: Oxford University Pres

Fields, D. L. (2002). Taking the measure of work: A guide to validated scales for organizational research and diagnosis. Sage publications Inc, Thousand Oaks, California.

George, J.M. (1991). State or trait: Effects of positive mood on prosocial behaviors at work. Journal of Applied Psychology, 76, 299-307

Göncü, A. (2006). Motivational Processes Involved in the Relationship Between Leadership and Organizational Citizenship Behaviors. Koç Üniversitesi Psikoloji Yüksek Lisans Tezi

Graham, J. W. (1989). 'Organizational citizenship behavior. Construct redefinition, operationaiization, and validation'. Unpublished working paper, Loyola University of Chicago, Chicago, IL.

Hale, J.R., \& Fields, D.L. (2007). Exploring servant leadership across cultures: A study of followers in Ghana and the USA. Leadership, 3, 397417.

Hofstede, G. (1980). Culture's Consequences, Beverly Hills, CA: Sage

House, R.J., Hanges, P.M., Javidan, M., Dorfman, P. \& Gupta, V. (2004). Culture, leadership, and organizations: The GLOBE study of 62 societies. Thousand Oaks, CA: Sage

Hui, C. H. and Triandis, H. C. (1986). Individualism-collectivism: A study of cross-cultural researchers. Journal of Cross-Cultural Psychology, $17,225-248$

Jenkins, D. (2005). 'Examining The Relationships Between The Satisfaction of Basic Psychological Needs, Employee Well-Being \& Commitment', Unpublished Master Dissertation, Carleton University, Ottowa, Ontorio.

Koh, W. L., Steers, R. M., \& Terborg, J. R. (1995). The effects of transformational leadership on teacher attitudes and student performance in Singapore. Journal of Organizational Behaviour, 16 (4), 319-333.

Kuşdil, M.E. \& Kağıtçıbaşı, Ç. (2000). Türk öğretmenlerin değerler yönelimi ve Schwartz değer kuramı. Türk Psikoloji Dergisi, 15 (45), $59-76$

Li, Y.C. (2004). Examining the effect of organizational culture and leadership behaviors on organizational commitment, job satisfaction and job performance at small and medium-sized firms of Taiwan. Journal of American Academy of Business, 5 (1/2), 432-438

Liden, R. C., Wayne, S. J., Zhao, H., \& Henderson, D. (2008). Servant leadership: development of a multidimensional measure and multilevel assessment. Leadership Quarterly, 19, 161-177.

Masterson, S.S., Lewis, K., Goldman, B.M. and Taylor, M.S. (2000). Integrating Justice and Social Exchange: The Differing Effects of Fair Work Procedures and Treatment on Work Relationships. Academy of Management Journal, 43 (4), 738-748.

McCrae, R.R. \& Costa, P.T.Jr. (1987). Validation of the five-factor model of personality across instruments and observers. Journal of Personality and Social Psychology, 52, 81-90

Moorman, R.H. (1991). The relationship between organizational justice and organizational citizenship behaviors: Do fairness perceptions influence employee citizenship? Journal of Applied Psychology, 76, 845-855.

Moorman, R. H. \& Blakely, G. L. (1995). Individualism-collectivism as an individual difference predictor of organizational citizenship behavior. Journal of Organizational Behavior, 16, 127-142.

Neubert, M.J., Kacmar, K.M., Carlson, D.S., Chonko, L.B., \& Roberts, J.A. (2008). Regulatory focus as a mediator of the influence of initiating structure and servant leadership on employee behavior. Journal of Applied Psychology, 93, 1220-1233.

Northouse, P. G.. (1997). Leadership: Theory and research. Thousand Oaks, CA: Sage.

Organ, D.W. (1988), Organizational Citizenship Behavior: The Good Soldier Syndrome, Lexington, M. A.: Lexington Books.

Organ, D.W. ve Ryan, K.A. (1995). Meta-Analytic Review of Attitudinal and Dispositional Predictors of Organizational Citizenship Behavior, Personnel Psychology, 48, 775-782.

Organ, D., (1997) Organizational Citizenship Behavior: It's Construct Clean-Up Time, Human Performance, 10, 85-97. 
Organ, D.W. \& Konovsky, M. (1989). Cognitive versus affective determinants of organizational citizenship behavior. Journal of Applied Psychology, 74, 157-164

Parkes, L.P., Bochner, S. \& Scheider, S.K. (2001). Person-organization fit across cultures: An empirical investigation of individualism and collectivism. Applied Psychology: An International Review, 50, 81-108

Parsons, T. and Shills, E. N. (1951). Toward a General Theory of Social Action, Cambridge: Harvard University Press

Penner, L. A.; Midili, A. R. ve Kegelmeyer, J. (1997). Beyond Job Attitudes: A Personality and Social Psychology Perspective on the Causes of Organizational Citizenship Behavior. Human Performance, 10 (2), 111-131.

Piccolo, R. F., Greenbaum, R., Den Hartog, D. N., \& Folger, R. (2010). The relationship between ethical leadership and core job characteristics. Journal of Organizational Behavior, 31, 259-278.

Podsakoff, P.M., MacKenzie, S.B., Moorman, R.H. \& Fetter, R. (1990). Transformational leader behaviors and their effects on followers' trust in leader, satisfaction, and organizational citizenship behavior. Leadership Quarterly, 1 (2), 107-142

Podsakoff, P.M., MacKenzie, S.B. \& Bommer, W.H. (1996). Transformatioanl leader behaviors and substitutes for leadership as determinants of employee satisfaction, commitment, trust and organizational citizenship behaviors. Journal of Management, 22 (2), 259298

Podsakoff, P.M., MacKenzie, S.B., Paine, J.B. \& Bachrach, D.G. (2000). Organizatioanl citizenship behaviors: A critical review of the theoretical and ampirical literature and suggestions for future research. Journal of Management, 26 (3), 513-563

Probst, T.M., Carnevale, P.J., Triandis, H.C. (1999). Cultural values in intergroup and single group social dilemmas. Organizational Behavior and Human Decision Processes, 77, 171-191.

Ramamoorthy, N; Kulkarni, S.P.; Gupta, A. \& Flood, P.C. (2007). Individualism-collectivism orientation and employee attitudes: A comparison of employees from the high-technology sector in India and Ireland. Journal of International Management, 13, 187-203

Rich, B.L., Lepine, J.A. \& Crawford, E.R. (2010). Job engagement: Antecedents and effects on job performance. Academy of Management Journal, 53 (3), 617-635

Rowold, J., \& Heinitz, K. (2007). Transformational and charismatic leadership: assessing the convergent, divergent and criterion validity of the MLQ and the CKS. Leadership Quarterly, 18, 121-133

Schappe, S.P., (1998) The Influence Of Job Satisfaction, Organizational Commitment, And Fairness perceptions On Organizational Citizenship Behavior, Journal of Psychology, 132, 277-290.

Singelis, T. M. (1994). The measurement of independent and interdependent selfconstruals. Personality and Social Psychology Bulletin, 20, 580-591.

Smith, C.A., Organ, D.W. \& Near, J.P. (1983). Organizational citizenship behavior: Its nature and antecedents. Journal of Applied Psychology, 68 (4), 653-663.

Triandis, H.C. (1995). Individualism and collectivism. Boulder, CO: Westview Press

Vondey, M. (2010). The Relationships among Servant Leadership, Organizational Citizenship Behavior, Person-Organization Fit, and Organizational Identification. International Journal of Leadership Studies, 6(1), 3-27.

Wagner, J. A., (1992). 'Individualism-collectivism and free riding: A study of main and moderator effects'. Paper presented at the 1992 Academy of Management Meetings, Las Vegas, NV.

Wagner, J. A., and Moch, M. K. (1986). Individualism-collectivism: Concept and measure. Group and Studies, II, 280-304.

Walumbwa, F.O., Hartnell, C.A ve Oke, A. (2010). Servant Leadership, Procedural Justice Climate, Service Climate, Employee Attitudes, and Organizational Citizenship Behavior: A Cross-Level Investigation. Journal of Applied Psychology, 95 (3), $517-529$

Wasti, A. ve Erdil, S.E. (2007). Bireycilik ve toplulukçuluk değerlerinin ölçülmesi: Benlik Kurgusu ve INDCOL ölçeklerinin Türkçe geçerlemesi. Yönetim Araştırmaları Dergisi, 2 (1-2), 39-66

Wayne, S.J \& Green, S.A (1993). The Effects of Leader-Member Exchange on Employee Citizenship and Impression Management Behavior. Human Relations 46, 1431-1440,

Williams, L.J. \& Anderson, S.E. (1991). Job satisfaction and organizational commitment as predictors of organizational citizenship behavior and in-role behaviors. Journal of Management, 17, 601-617

Yiing, L.H. \& Ahmad, K.Z.B. (2009). The moderating effects of organizational culture on the relationships between leadership behavior and organizational commitment and between organizational commitment and job satisfaction and performance. Leadership \& Organization Development Journal, 30 (1), 55-86 